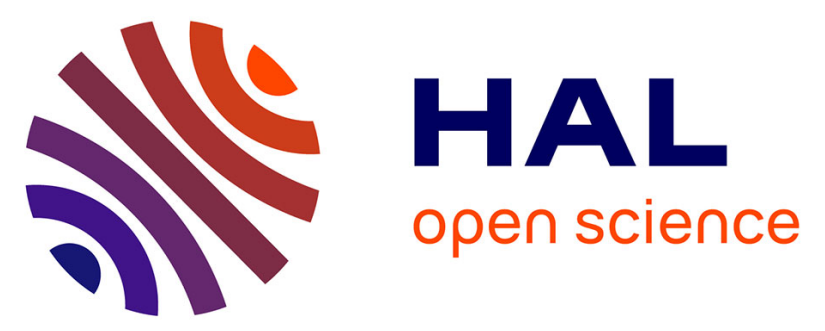

\title{
Magnetron Sputtered Al-CuO Nanolaminates: Effect of Stoichiometry and Layers Thickness on Energy Release and Burning Rate
}

Mehdi Bahrami, Guillaume Taton, Véronique Conédéra, Ludovic Salvagnac, Christophe Tenailleau, Pierre Alphonse, Carole Rossi

\section{To cite this version:}

Mehdi Bahrami, Guillaume Taton, Véronique Conédéra, Ludovic Salvagnac, Christophe Tenailleau, et al. Magnetron Sputtered Al-CuO Nanolaminates: Effect of Stoichiometry and Layers Thickness on Energy Release and Burning Rate. Propellants, Explosives, Pyrotechnics, 2014, 39 (3), pp.365-373. 10.1002/prep.201300080 . hal-03464968

\section{HAL Id: hal-03464968 https://hal.science/hal-03464968}

Submitted on 3 Dec 2021

HAL is a multi-disciplinary open access archive for the deposit and dissemination of scientific research documents, whether they are published or not. The documents may come from teaching and research institutions in France or abroad, or from public or private research centers.
L'archive ouverte pluridisciplinaire HAL, est destinée au dépôt et à la diffusion de documents scientifiques de niveau recherche, publiés ou non, émanant des établissements d'enseignement et de recherche français ou étrangers, des laboratoires publics ou privés. 


\section{Open Archive TOULOUSE Archive Ouverte (OATAO)}

OATAO is an open access repository that collects the work of Toulouse researchers and makes it freely available over the web where possible.

This is an author-deposited version published in : http://oatao.univ-toulouse.fr/ Eprints ID : 13968

To link to this article : DOI: $10.1002 /$ prep.201300080

URL : http://dx.doi.org/10.1002/prep.201300080

\section{To cite this version:}

Bahrami, Mehdi and Taton, Guillaume and Conédéra, Véronique and Salvagnac, Ludovic and Tenailleau, Christophe and Alphonse, Pierre and Rossi, Carole Magnetron Sputtered Al-CuO Nanolaminates: Effect of Stoichiometry and Layers Thickness on Energy Release and Burning Rate. (2014) Propellants, Explosives, Pyrotechnics, vol. 39 ( $\mathrm{n}^{\circ}$ 3). pp. 365-373. ISSN 0721-3115

Any correspondance concerning this service should be sent to the repository administrator: staff-oatao@ listes-diff.inp-toulouse.fr 


\title{
Magnetron Sputtered Al-CuO Nanolaminates: Effect of Stoichiometry and Layers Thickness on Energy Release and Burning Rate
}

\author{
Mehdi Bahrami, ${ }^{[a]}$ Guillaume Taton, ${ }^{[a]}$ Véronique Conédéra, ${ }^{[a]}$ Ludovic Salvagnac, ${ }^{[a]}$ Christophe Tenailleau, ${ }^{[b]}$ \\ Pierre Alphonse, ${ }^{[b]}$ and Carole Rossi ${ }^{*[a]}$
}

\begin{abstract}
This paper reports on the reaction characteristic of $\mathrm{Al} / \mathrm{CuO}$ reactive nanolaminates for different stoichiometries and bilayer thicknesses. Al/CuO nanolaminates are deposited by a DC reactive magnetron sputtering method. Pure $\mathrm{Al}$ and $\mathrm{Cu}$ targets are used in argon-oxygen gas mixture plasma and an oxygen partial pressure of $0.13 \mathrm{~Pa}$. This process produces low stress multilayered materials, each layer being in the range of 25 nanometers to one micrometer. Their structural, morphological, and chemical properties were characterized by high resolution transmission electron microscopy (HR-TEM), X-ray Diffraction (XRD), and X-ray photoelectron spectroscopy (XPS). The heat of reaction and
\end{abstract}

Keywords: $\mathrm{Al} / \mathrm{CuO} \cdot$ Nanothermites $\cdot$ Reactive material $\cdot$ Nanoenergetics onset temperature were measured using differential scanning calorimetry (DSC). Under stoichiometric conditions, the reactivity quickly increases with the decrease of $\mathrm{Al} / \mathrm{CuO}$ bilayer thickness. The burning rate is $2 \mathrm{~m} \mathrm{~s}^{-1}$ for bilayer thickness of $1.5 \mu \mathrm{m}$ and reaches $80 \mathrm{~m} \mathrm{~s}^{-1}$ for bilayer thickness of $150 \mathrm{~nm}$. At constant heating rate, the $\mathrm{Al} / \mathrm{CuO}$ heat of reaction depends on both stoichiometry and bilayer thickness. When the bilayer thickness exceeds $300 \mathrm{~nm}$, the heat of reaction decreases; it seems that only the region near the interface reacts. The best nanolaminate configuration was obtained for $\mathrm{Al} / \mathrm{CuO}$ bilayer thickness of $150 \mathrm{~nm}$.

\section{Introduction}

Nanostructured metallic and composite materials are becoming essential to 21st century industries [1-3] as they are giving the opportunity to address a number of key technological challenges in a broad range of applications such as energy [3,4], environment [5], security, and medicine [6] to name just a few. Among such advanced materials, nanolaminates - defined as stacks of alternating ultrathin layers of different materials - have originated interest due to their compatibility and enhanced properties for microelectronics and MEMS technologies. A variety of techniques have been used to synthesize them, such as Atomic Layer Deposition to deposit oxide/oxide and oxide/metal systems [7-10], Pulsed Laser Deposition, aqueous solution depositions to produce high-quality oxide/oxide nanolaminates [11,12], Physical Vapor Deposition (PVD) to manufacture metal/metal systems [13-15], and reactive metal/oxide systems [16-20].

Reactive nanolaminates containing $\mathrm{Al}$ and one metallic oxide (as $\mathrm{CuO}, \mathrm{Fe}_{2} \mathrm{O}_{3}, \mathrm{NiO}$ ) have attracted great interest in the nano energetic material community $[18,19,21-27]$ since they are characterized by a high energy and power density (superior to supercapacitors) and offer numerous advantages over nanopowder mixing. Each deposited metal and oxide layer can be accurately controlled in thickness (from a few nanometers to several hundreds of nano- meters) to tailor the reactivity of the energetic layer. The purity is also particularly high since the deposition is made at very low pressure and ambient temperature. The resulting energetic layer has a uniform layering and interface placing the reactants in intimate contact, which is not the case with any mechanical processing technique. Furthermore, the PVD method allows integrating the nanolaminate directly on the electronic device without manipulating dangerous reactants or reactive nanopowders, which makes the process and material very safe and attractive for commercial products. This new technological field called Nanoenergetics-On-a-Chip $[3,27]$ is particularly interesting to provide on-chip tunable heat burst liberated by a low-energy impulse with microsecond initiation response $[3,4,27,28]$.

[a] M. Bahrami, G. Taton, V. Conédéra, L. Salvagnac, C. Rossi LAAS

CNRS, Université de Toulouse

7 Avenue du Colonel Roche

31400 Toulouse, France

*e-mail: rossi@laas.fr

[b] C. Tenailleau, P. Alphonse

CIRIMAT

UMR CNRS 5085

118 Route de Narbonne

31062 Toulouse Cedex 9, France 
In that context, our research team has explored the sputter deposition of $\mathrm{Al} / \mathrm{CuO}$ nanolaminates [18]. Both $\mathrm{Al}$ (fuel) and $\mathrm{CuO}$ (oxidizer) are common in MEMS and safe; also, $\mathrm{Al}+$ CuO reaction is among the most exothermic one with a maximum theoretical heat release of $3.9 \mathrm{~kJ} \mathrm{~g}^{-1}$ close to that of TNT [29]. Previous works have been performed to prepare and characterize $\mathrm{Al} / \mathrm{CuO}$ multilayers $[16,18,19,30]$.

In this work, the preparation of $\mathrm{Al} / \mathrm{CuO}$ nanolaminates is briefly summarized. The as-deposited nanolaminates were characterized with a variety of ex-situ analytical techniques (HR-TEM, XRD, STEM-EDX, XPS) to analyze the Al and CuO layers and interface morphology as well as the chemical nature of both layers and interface. Then it was examined the relationship between the stoichiometry and the layer thickness and the resulting reaction properties. For that purpose, $\mathrm{Al} / \mathrm{CuO}$ nanolaminates with different mass equivalence ratios and variable $\mathrm{Al} / \mathrm{CuO}$ bilayer thicknesses were prepared and their reaction properties (heat and burning rate) were analyzed. The $\mathrm{Al} / \mathrm{CuO}$ exothermic reaction was examined under constant heating rate using Differential Scanning Calorimetry (DSC). The burning rate was measured with a high speed camera.

In this paper, the experimental deposition and characterization techniques are summarized in Section 2. Section 3 is devoted to the presentation and discussion of the results. The structural and chemical properties of the deposited layers and the effect of stoichiometry on the released heat of reaction and on the burning rates were successively examined. Conclusions are drawn in Section 4.

\section{Experimental Methods}

\subsection{Materials}

$\mathrm{Al} / \mathrm{CuO}$ nanolaminates are magnetron sputter deposited on silicon wafers using $\mathrm{Al}$ and $\mathrm{Cu}$ targets. Before processing, the wafers were rinsed in deionized water baths and dried under nitrogen flux. During the sputter deposition, the temperature of the substrate was regulated at $10^{\circ} \mathrm{C}$ and the residual pressure in the chamber was approx. $10^{-5} \mathrm{~Pa}$. Thin copper oxide films were deposited by dc reactive magnetron sputtering method under argon and oxygen plasma at $400 \mathrm{~W}$, using a Cu target (purity >99,999\%). Oxygen partial pressure was of $0.13 \mathrm{~Pa}$. Thin aluminum films were also deposited by dc reactive magnetron sputtering from an Al target (purity $>99,999 \%$ ) under argon plasma at $800 \mathrm{~W}$. The silicon substrate was successively exposed to $\mathrm{CuO}$ (first layer) and $\mathrm{Al}$ (second layer) without changing the chamber. After the CuO layer deposition, the chamber was automatically pumped out to remove oxygen in order to prevent aluminum oxidation during the Al deposition cycle. Each layer thickness was between $50 \mathrm{~nm}$ and $1 \mu \mathrm{m}$ with a thickness accuracy of $5 \mathrm{~nm}$.

To obtain free standing foils, prior to nanolaminate deposition the silicon wafer was first spin coated with a layer of photoresist and baked at $110^{\circ} \mathrm{C}$ for $90 \mathrm{~s}$. Then, the wafers were rinsed in acetone to dissolve the resist. Before any characterization, the so-fabricated and released foils were stored at ambient conditions for one week.

The mass equivalence ratio $\varnothing$ is defined according to the following Equation (1):

$\varnothing=\frac{\left(m_{\mathrm{Al}} / m_{\mathrm{CUO}}\right)_{\text {SAMPLE }}}{\left(m_{\mathrm{Al}} / m_{\mathrm{CUO}}\right)_{S T}}$

In this equation, $m_{\mathrm{Al}}$ and $m_{\mathrm{CuO}}$ stand for mass of $\mathrm{Al}$ and CUO, respectively. SAMPLE indicates the actual ratio and ST indicates the stoichiometric ratio. The stoichiometric mixture fraction corresponds to $18 \%$ of $\mathrm{Al}$ in mass or $33 \%$ of $\mathrm{Al}$ in volume. Fixing $\mathrm{Al}$ thickness at $100 \mathrm{~nm}$, different thicknesses of $\mathrm{CuO}$ films were deposited to span the mass equivalence ratio $\varnothing$ from $2 / 3$ to 4 . Then, for $\varnothing=1$, different bilayer thicknesses were deposited to study the influence of the bilayer thickness on the reaction properties.

\subsection{Transmission Electron Microscopy - Scanning Electron Microscopy - Energy Dispersive X-ray Spectroscopy}

The morphology of $\mathrm{CuO}$, and $\mathrm{Al}$ layers and layer interfaces was observed by HR-TEM and STEM with a JEOL Jsm $2100 \mathrm{~F}$ instrument operating at a maximum voltage of $200 \mathrm{kV}$. For HR-TEM study, the foils were not removed from the substrate. TEM samples were ion-beam milled in the Gatan PIPS (Precision lon Polishing System). Digital images were obtained with a CDD Gatan 794 Camera $(1 \mathrm{~K} \times 1 \mathrm{~K})$ and the Energy Dispersive X-ray Spectroscopy (EDXS) analyses were performed with a SDD Bruker detector.

\subsection{X-ray Photoelectron Spectroscopy}

Using a Thermoscientific Kalpha equipment, XPS analyses were performed on the surface of two bilayers: CuO$50 \mathrm{~nm} / \mathrm{Al}-50 \mathrm{~nm}$ and Al-50 nm/CuO-50 nm. The photoelectron emission spectra were recorded using $\mathrm{Cu}-K_{\alpha}$ line $(1486.6 \mathrm{eV})$ with a monochromatized source. The X-ray spot was approximately of $400 \mu \mathrm{m}$. The pass energy was fixed at $30 \mathrm{eV}$ with an energy step size of $0.1 \mathrm{eV}$, the dwell time is $50 \mathrm{~ms}$. The spectrometer energy calibration was made using the $\mathrm{Au} 4 \mathrm{f} 7 / 2 \quad(83.9 \mathrm{eV} \pm 0.1 \mathrm{eV})$ and $\mathrm{Cu} 2 \mathrm{p} 3 / 2$ $(932.8 \mathrm{eV} \pm 0.1 \mathrm{eV})$ photoelectron lines. XPS spectra were recorded in direct $N(E c)$. The background signal was removed using the Shirley method. The argon ion etching in the XPS system was performed at $1 \mathrm{keV}$ with a very low ion current density. It gives a penetration rate of about $0.05 \mathrm{~nm} \mathrm{~s}^{-1}$. The argon gas purity is $99.999 \%$. The vacuum in XPS analysis chamber was about $1 \times 10^{-9} \mathrm{~Pa}$ before the ion etching. The atomic concentrations were determined with accuracy better than $10 \%$, from photoelectron peak areas using the atomic sensitivity factors reported by Scofield and taking into account the transmission function of the analyzer. This function was calculated at different pass energies from $\mathrm{Ag}$ $3 \mathrm{~d}$ and $\mathrm{Ag}$ MNN peaks collected for a silver reference 
sample. The binding energy scale was established by referencing the Si $2 p$ value at $99.0 \mathrm{eV}( \pm 0.1 \mathrm{eV})$.

\subsection{Thermal Analysis}

$\mathrm{Al} / \mathrm{CuO}$ exothermic reactions were characterized by DSC with a constant heating rate of $10^{\circ} \mathrm{C} \mathrm{min}^{-1}$ with a MettlerToledo device equipped with a HSS8 sensor and in the temperature range of $30^{\circ} \mathrm{C}$ to $700^{\circ} \mathrm{C}$. The flowing gas was $99.999 \%$ argon purified by passing through an oxygen trap (Supelco). About $10 \mathrm{mg}$ of $\mathrm{Al} / \mathrm{CuO}$ nanolaminates were placed in a $40 \mu \mathrm{L}$ platinum pan. After the first heating cycle, the sample was cooled down to room temperature and then heated again at the same heating rate. This second analysis was used to correct the baseline. It is assumed that the bulk heat capacity of the sample does not change between the first and the second heating. After thermal analysis, X-ray diffraction pattern of the sample was collected with a Bruker D5000 X-ray diffractometer with $\mathrm{Cu}-K_{\alpha}$ radiation source $(40 \mathrm{kV}, 40 \mathrm{~mA})$ in a 2-theta range $20-80 \mathrm{deg}$ (24 s/0.03 deg).

\subsection{Burning Rate Measurements}

The test bench consisted in an open tray of $60 \mathrm{~mm}$ length, $5 \mathrm{~mm}$ width, and $5 \mathrm{~mm}$ depth, in which the $\mathrm{Al} / \mathrm{CuO}$ foils were placed. The propagation of the flame front was recorded using a high speed camera SA3 photron able to capture the visible light. Figure 1 is an example of the visible light acquired with the high speed camera with a sampling rate of 25,000 frames per second. To calculate the mean burning rate, it is assumed that the flame propagates at constant rate.

\section{Results and Discussion}

\subsection{Structure and Morphology of $\mathrm{CuO}$ and Interfaces}

The HR-TEM micrograph of Figure 2(a) shows the columnar structure of the $\mathrm{CuO}$ film. This columnar growth may come from the fact that the deposition temperature is low compared to the CuO melting point $\left(1320^{\circ} \mathrm{C}\right)$. It has been reported that the structure of vapor deposited films grown under these conditions consists typically of columnar polycrystalline structures with voided open boundaries [31]. The as-deposited $\mathrm{CuO}$ film roughness was measured at 2$3 \mathrm{~nm}$ for $50 \mathrm{~nm}$ thick $\mathrm{CuO}$ film and $7-8 \mathrm{~nm}$ for $200 \mathrm{~nm}$ thick CuO film.

During sputter deposition, an intermixing naturally occurs between $\mathrm{Al}$ and $\mathrm{CuO}$ layers to form a diffusion barrier layer (see Figure 2); the thickness and chemical nature of this diffusion barrier layer greatly depend on the deposition conditions and can affect the reaction kinetics [32]. Interestingly, the interface layers observed in our nanolaminate foils are not symmetric. The TEM photo of Figure 2(c) corresponds to the deposition of $100 \mathrm{~nm}$ of $\mathrm{CuO}$ on $50 \mathrm{~nm}$ thick
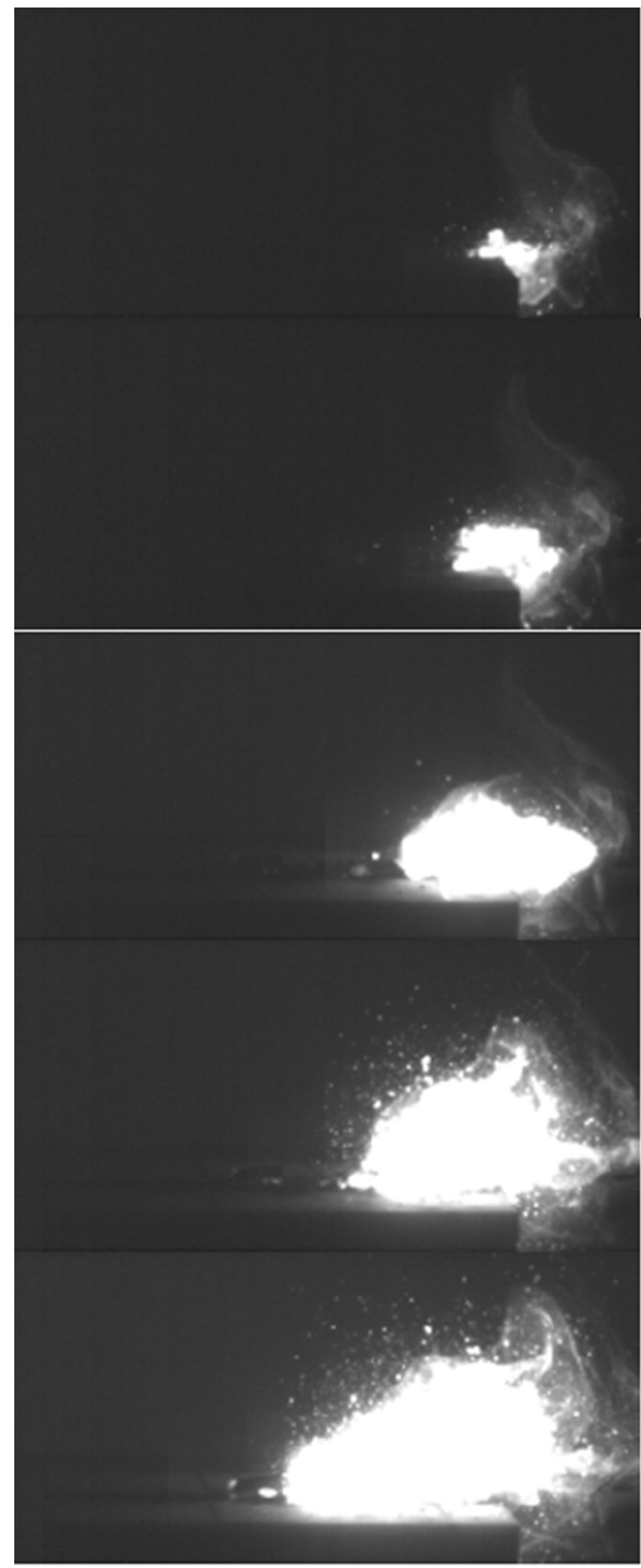

Figure 1. Al/CuO nanolaminates flame propagation in air.

Al film: the resulting interface is regular in thickness with an average thickness of approx. $4 \mathrm{~nm}$ (between 3 and 


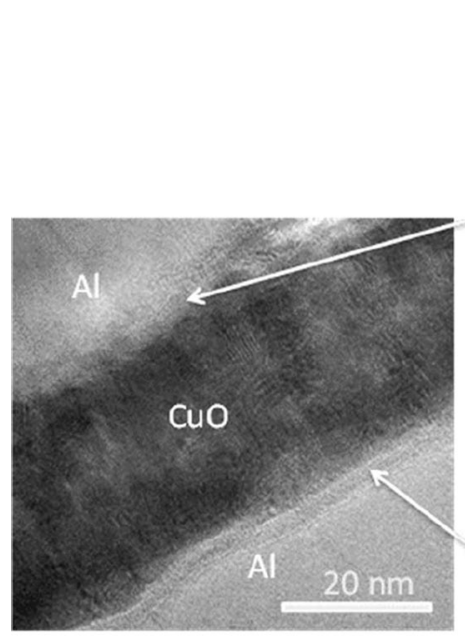

(a)

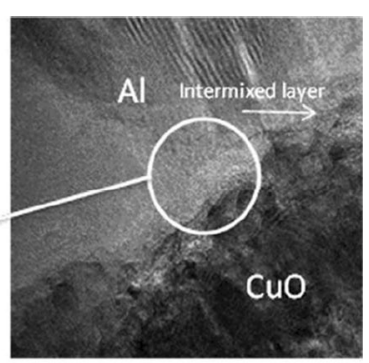

(b)

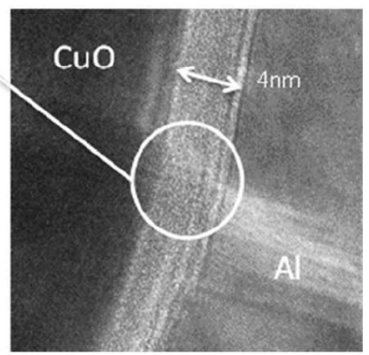

(c)

Figure 2. HR-TEM micrographs of (a) the $\mathrm{CuO} / \mathrm{Al}$ nanolaminates showing the columnar grain structure of the CuO layer (dark part) and the grains in the Al layer (lighter contrast); (b) sputter-deposited $\mathrm{Al}$ onto $\mathrm{CuO}$; (c) sputter-deposited $\mathrm{CuO}$ onto Al.

$5 \mathrm{~nm})$, and amorphous. It is likely that an $\mathrm{Al}_{x} \mathrm{O}_{y}$ layer is formed when $\mathrm{O}_{2}$ plasma is generated inside the chamber just before starting the Cu sputtering; in other words, the neat Al surface is first bombarded with $\mathrm{O}$ atoms or $\mathrm{O}_{2}$ molecules (before sputtering starts) and then with sputtered $\mathrm{Cu}$ from the $\mathrm{Cu}$ target. It is also noted that this interface formed after sputtering of $\mathrm{CuO}$ onto $\mathrm{Al}$ is thicker than the native $\mathrm{Al}$ oxide. This effect has been seen in powder mixtures of $\mathrm{Al} / \mathrm{Cu}_{2} \mathrm{O}$. Moddeman et al. found that the thickness of the oxide layer on Al powders was increased when compacted with $\mathrm{Cu}_{2} \mathrm{O}$ powder [33]. The HR-TEM photo of Figure 2(b) corresponds to the interface formed by the sputtering of $\mathrm{Al}$ onto $\mathrm{CuO}$, which appears overall ill-defined and most likely composed of a mixture of $\mathrm{Al}, \mathrm{Cu}, \mathrm{O}$. An interface layer narrowing at some points is also observed, certainly because it is difficult to obtain a conformal interface on the highly textured and irregular $\mathrm{CuO}$ surface.

Two-dimensional STEM-EDX analysis was performed with Al-100 nm/CuO-200 nm/Al-100 nm foils deposited on native oxidized silicon substrate. The EDX elemental mappings of $\mathrm{Al}, \mathrm{Cu}, \mathrm{O}$, and Si (Figure 3) confirm the presence of each expected elements in each layer. It is also seen that the density of oxygen atoms is higher at the interface regions confirming the hypothesis of oxygen trapped at the interface. It is also noted that the oxygen atoms are not homogeneously distributed over the thickness of the CuO layer. The EDX spectrum of the interfacial layer clearly confirms the presence of $\mathrm{Cu}, \mathrm{Al}$, and $\mathrm{O}$ atoms. However, STEM-EDX analysis cannot give any precise information about the origin
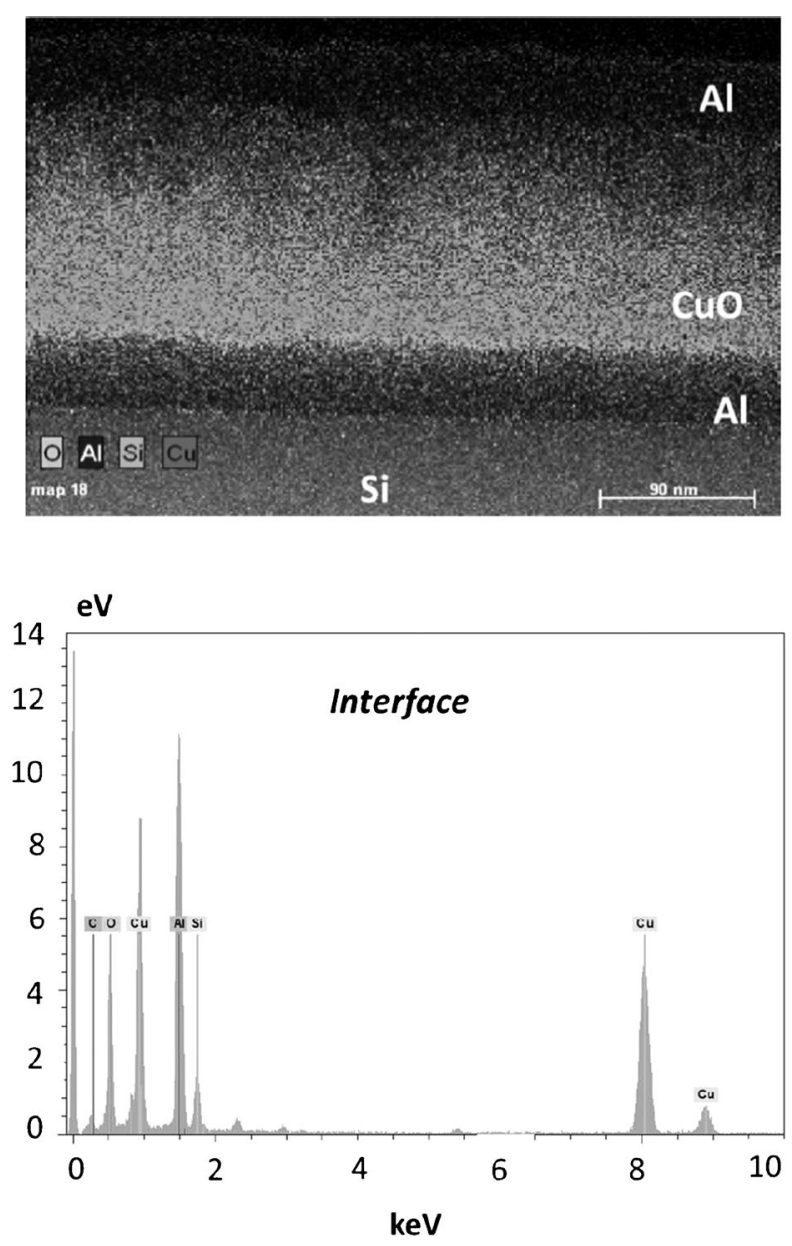

Figure 3. Elemental mapping (EDX) of $\mathrm{O}, \mathrm{Al}, \mathrm{Cu}$, and $\mathrm{Si}$ in $100 \mathrm{~nm}$ $\mathrm{Al} / 200 \mathrm{~nm}-\mathrm{CuO} / 100 \mathrm{~nm}$-Al nanolaminates deposited on $\mathrm{Si}$ substrate and the corresponding spectrum at the interface.

of the oxygen atoms trapped at the interface: are they coming from the $\mathrm{O}_{2}$ plasma just before depositing the $\mathrm{CuO}$ from $\mathrm{Cu}$ target or do they migrate from the $\mathrm{CuO}$ layer to the interface? This second possibility appears to be the most probable since both interfaces (when Al is deposited on $\mathrm{CuO}$ and inversely) have high densities of oxygen.

\subsection{Chemical Analysis of $\mathrm{Al} / \mathrm{CuO}$ and $\mathrm{CuO} / \mathrm{Al}$ Bilayers}

For the chemical study, the O $1 s, \mathrm{Al}(2 \mathrm{p}$ and $2 \mathrm{~s}), \mathrm{Cu} 2 \mathrm{p}$, and $\mathrm{Si} 2 \mathrm{p}$ spectra were acquired on both $\mathrm{Al} / \mathrm{CuO}$ and $\mathrm{CuO} / \mathrm{Al}$ bilayers and as a function of etch time. Both chemical profiles are given in Figure 4(a) and (b). Cu LMM was used to confirm the state of $\mathrm{Cu}$.

\subsubsection{Al on CuO}

On the surface, in region I of Figure 4(a), XPS spectra confirm Al metal at $72.7 \mathrm{eV}(2 \mathrm{~s}$ at $117.8 \mathrm{eV}$ ) and $\mathrm{Al}$ oxide $\left(\mathrm{Al}_{2} \mathrm{O}_{3}\right)$, which is at $75.4 \mathrm{eV}(2 \mathrm{~s}$ at $120.2 \mathrm{eV})$. The aluminum surface is oxidized and has also carbon contamination $(<$ 

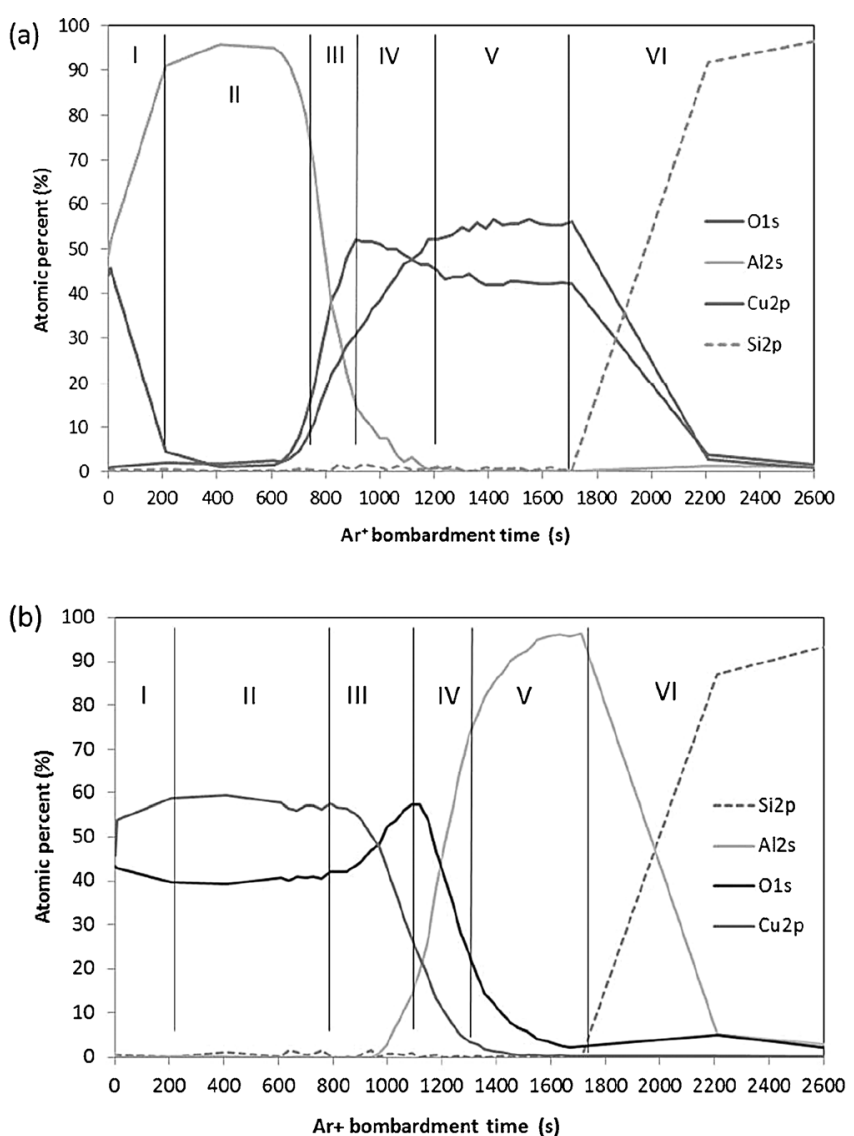

Figure 4. Chemical profile as a function of the $\mathrm{Ar}^{+}$bombardment time in (a) $\mathrm{Al} / \mathrm{CuO}$ bilayer; (b) $\mathrm{CuO} / \mathrm{Al}$ bilayer; interface corresponds to region between III and IV.

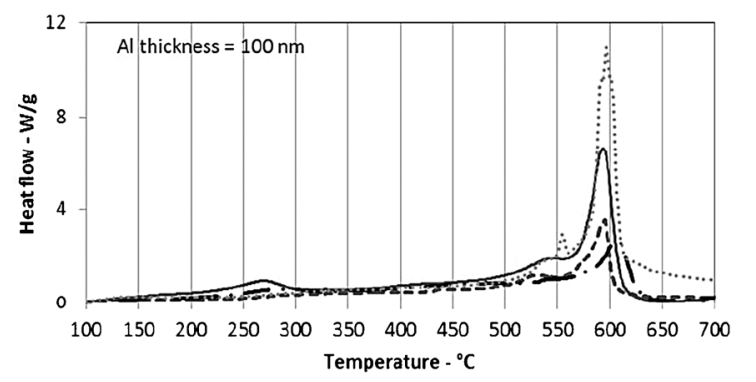

$---100 \mathrm{~nm}-\mathrm{Al} / 50 \mathrm{~nm}-\mathrm{CuO}(\varnothing=4) \quad-100 \mathrm{~nm}-\mathrm{Al} / 200 \mathrm{~nm}-\mathrm{CuO}(\varnothing=1)$

Figure 5. DSC curves of $\mathrm{Al} / \mathrm{CuO}$ nanolaminates heated at $10^{\circ} \mathrm{C} \mathrm{min}^{-1}$ and for different equivalence ratios.

$8 \% \mathrm{At}-\%)$ (not represented in the graph). In region II, [AI oxide]/[Al metal] ratio decreases and quickly the Al oxide concentration [Al oxide] disappeared. Al becomes more metallic at $72.7 \mathrm{eV}(2 \mathrm{~s}$ at $117.8 \mathrm{eV})$. There is also a few copper, which appears to be linked to Al atoms at $933.7 \mathrm{eV}$. Then, the intermixed interface can be split into two regions: region III is a mix of $\mathrm{Al}$ oxide ( $2 \mathrm{~s}$ at about $120 \mathrm{eV}$ ) and $\mathrm{Al}$ metal ( $2 \mathrm{~s}$ at $117.8 \mathrm{eV}$ ) with a major proportion of $\mathrm{Al}$ metal. The $\mathrm{Cu} 2 \mathrm{p}$ spectrum indicates mainly unoxidized $\mathrm{Cu}$ $(932.7 \mathrm{eV})$. In region IV [Al oxide] decreases ( $2 \mathrm{~s}$ at $118.6 \mathrm{eV}$ ), which is caused by the diminution of the concentration of oxygen atoms. $\mathrm{Cu}$ is present in copper oxide form with $[\mathrm{Cu}] /[\mathrm{O}]>1.5(932.4 \mathrm{eV})$. In region $\mathrm{V}, \mathrm{Cu}$ is still present in the form of copper oxide with $[\mathrm{Cu}] /[\mathrm{O}]$ of about 1.3 $(932.5 \mathrm{eV})$. Some oxygen atoms seem to have migrated from $\mathrm{CuO}$ to the interface to bond with Al. No aluminum is detected in the copper oxide phase. Finally, in the last region $\mathrm{Vl}, \mathrm{Cu}$ oxide concentration decreases and $\mathrm{Si}$ substrate appears in majority at $99.0 \mathrm{eV}$.

\subsubsection{CuO on $\mathrm{Al}$}

At the surface, in region I, XPS spectra involve $\mathrm{CuO}$ at $933 \mathrm{eV}$. Then, in region II, the oxide stoichiometry changes and becomes copper-rich with a $[\mathrm{Cu}] /[\mathrm{O}]$ ratio equal at 1.4 (932.4 eV). The region III is composed of copper-rich oxide with a $[\mathrm{Cu}] /[\mathrm{O}]$ ratio $<2$ and of an alumina-based oxide $\left(\mathrm{AlO}_{x}\right)(932.5 \mathrm{eV})$. In region $\mathrm{IV}_{1} \mathrm{Al}_{2} \mathrm{O}_{3}$ is found in major proportion at $75.5 \mathrm{eV}(2 \mathrm{~s}$ at $120.2 \mathrm{eV})$, some copper oxide with $[\mathrm{Cu}] /[\mathrm{O}]>2$ at $932.5 \mathrm{eV}$ and $\mathrm{Al}$ metal at $72.6 \mathrm{eV}(2 \mathrm{~s}$ at $117.8 \mathrm{eV}$ ). Then in region $\mathrm{V}, \mathrm{Al}$ metal is found in major proportion at $72.6 \mathrm{eV}(2 \mathrm{~s}$ at $117.8 \mathrm{eV})$ and some traces of $\mathrm{Al}_{2} \mathrm{O}_{3}$ at $75.5 \mathrm{eV}$ ( $2 \mathrm{~s}$ at $120.2 \mathrm{eV}$ ). The copper oxide concentration decreases to zero. In last region $\mathrm{VI}$, the $\mathrm{Al}$ concentration decreases and the Si substrate appears in majority at $99.0 \mathrm{eV}$.

\subsection{Effect of Stoichiometry and Bilayer Thickness on Heat of Reaction at Constant Heating}

To evaluate quantitatively the effect of $\mathrm{Al} / \mathrm{CuO}$ stoichiometry on the thermal decomposition, different samples with mass equivalence ratio from $2 / 3$ (fuel poor) to 4 (fuel rich) were analyzed by DSC. In this section, the Al film thickness is fixed at $100 \mathrm{~nm}$ and the total mass of Al is kept constant for all samples. For each value of the mass equivalence, three samples were tested and the average value is given in the graph of Figure 5.

All materials released heat upon thermal heating. The main exothermic peak is observed in the range of 590$615^{\circ} \mathrm{C}$ (onset is around $400^{\circ} \mathrm{C}$ ) for $\varnothing=1$ and 2 . Minor exothermic peaks are also detected at lower temperatures. The weak exothermic peak observed in the range of $250-300^{\circ} \mathrm{C}$ (especially visible for $\varnothing=1$ ) could be due either to recrystallization of native $\mathrm{Al}_{x} \mathrm{Cu}_{y} \mathrm{O}_{z}$ interface or caused by the reduction of $\mathrm{CuO}$ known to occur near $200^{\circ} \mathrm{C}$. Lee et al. [34] have reported that $\mathrm{CuO}$ starts to decompose into $\mathrm{Cu}_{2} \mathrm{O}$ at around $200^{\circ} \mathrm{C}$ under vacuum annealing. The weakly low exothermic peaks can play a role in the ignition phenomena (which appears to be the case for $\varnothing=2$ ). Umbrajkar et al. [35] and Ermoline et al. [36] have proposed that Cabrera-Mott kinetics describes the low temperature redox reaction (from ambient to $327^{\circ} \mathrm{C}$ ) in fully dense $\mathrm{Al} / \mathrm{CuO}$ nanocomposite. These DSC results are in agreement with DSC data published by Stamatis et al. [37] with a reaction tem- 


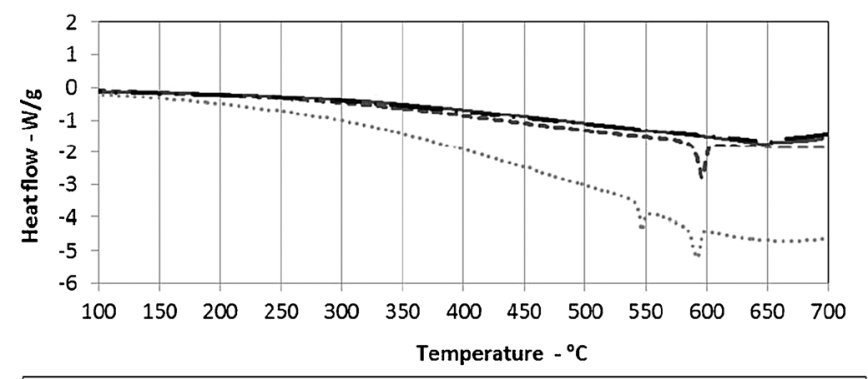

$--100 \mathrm{~nm}-\mathrm{Al} / 50 \mathrm{~nm}-\mathrm{CuO}(\varnothing=4) \quad-\mathrm{nm} / 200 \mathrm{~nm}-\mathrm{CuO}(\varnothing=1)$

Figure 6. DSC second heating curves of $\mathrm{Al} / \mathrm{CuO}$ nanolaminates heated at $10{ }^{\circ} \mathrm{Cmin}^{-1}$ and for different equivalence ratios.

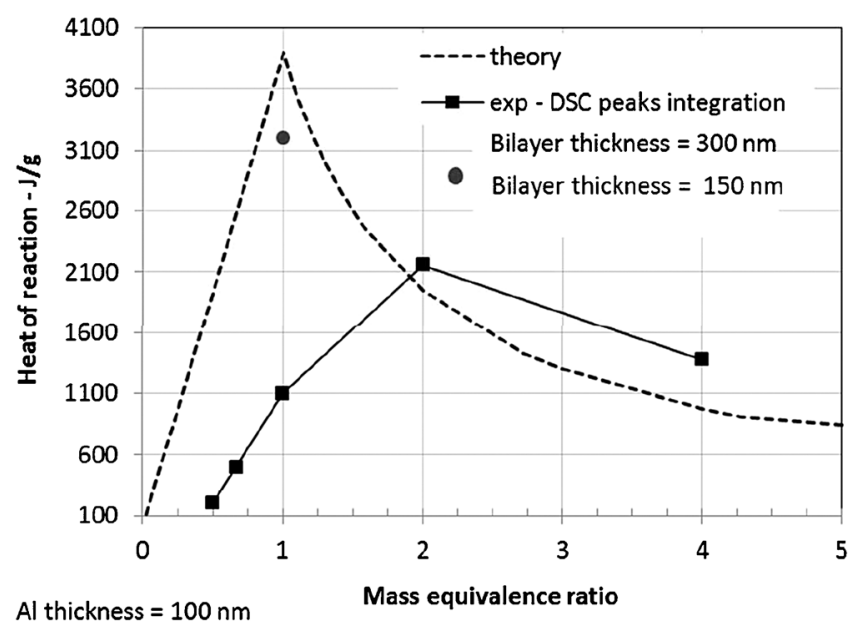

Figure 7. Heat of reaction as a function of the equivalence ratio.

perature of $600^{\circ} \mathrm{C}$ for Al-rich $\mathrm{Al}-\mathrm{CuO}$ nanothermites. For fuel-rich samples, the DSC curves, recorded during the second heating ramp, show an endothermic peak corresponding to the melting of $\mathrm{Al}$ in excess (see Figure 6). It is noticed that for $100 \mathrm{~nm}-\mathrm{Al} / 100 \mathrm{~nm}-\mathrm{CuO}$ foils $(\varnothing=2)$, this peak is observed at lower temperature than for $100 \mathrm{~nm}-\mathrm{Al} /$ $50 \mathrm{~nm}-\mathrm{CuO}(\varnothing=4)$ foils. The melting temperature is significantly lower than the bulk aluminum melting temperature $\left(660^{\circ} \mathrm{C}\right)$. For $100 \mathrm{~nm}-\mathrm{Al} / 100 \mathrm{~nm}-\mathrm{CuO}$ samples, an endotherm at $548^{\circ} \mathrm{C}$ that corresponds to the eutectic temperature of Al-Cu system is noted.

The total heat of reaction, calculated by integrating the DSC curves over the time (in the $400-600^{\circ} \mathrm{C}$ range) and normalized with respect to the sample mass, is plotted as a function of $\varnothing$ in Figure 7. Interestingly, it becomes obvious that the experimental data are not in complete agreement with the calculated ones, since the maximum is obtained for $\varnothing=2$; however they follow the same trend. This could be due to the fact that interface contribution is not taken into account in calculation but also because sputtered copper oxide is not pure cupric oxide over the foil thickness as described in Section 3.2.
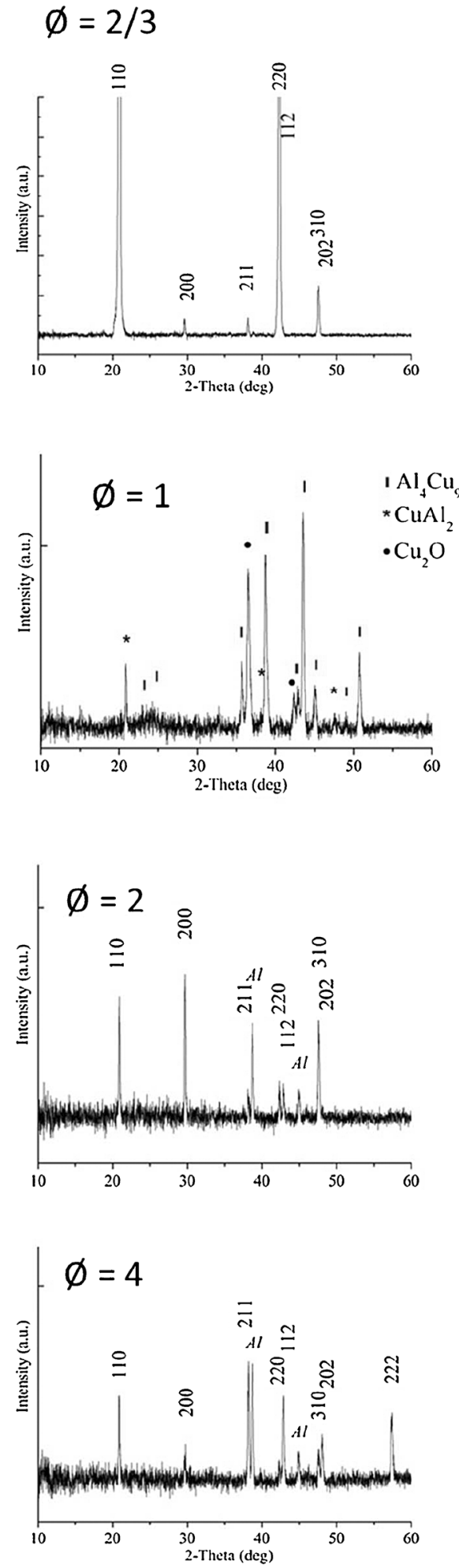

Figure 8. XRD patterns on reacted foils (after DSC experiments).

The low measured heats of reaction are due to incomplete reaction during the DSC scans, as seen in the XRD data of scanned samples. Figure 8 gives the XRD patterns of reacted foils (after the DSC). The indexed peaks corre- 


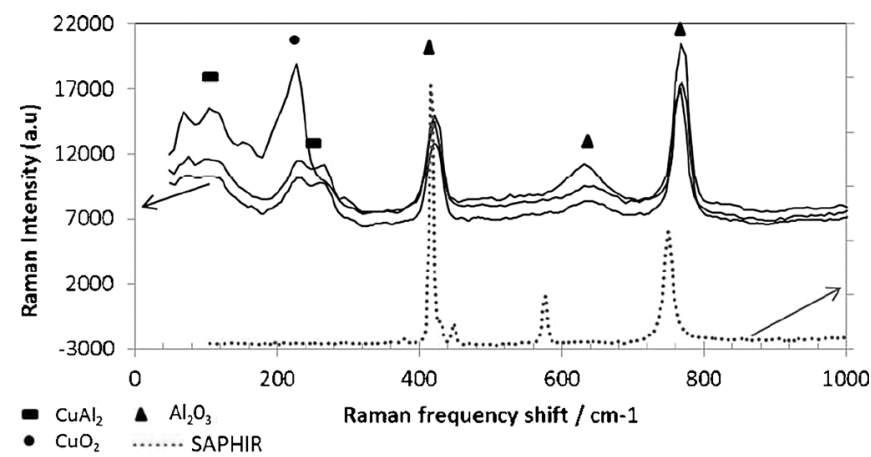

Figure 9. Raman spectra on reacted foils - as illustration $\varnothing=$ 1 sample is given. The three black curves correspond to three different points on the sample.

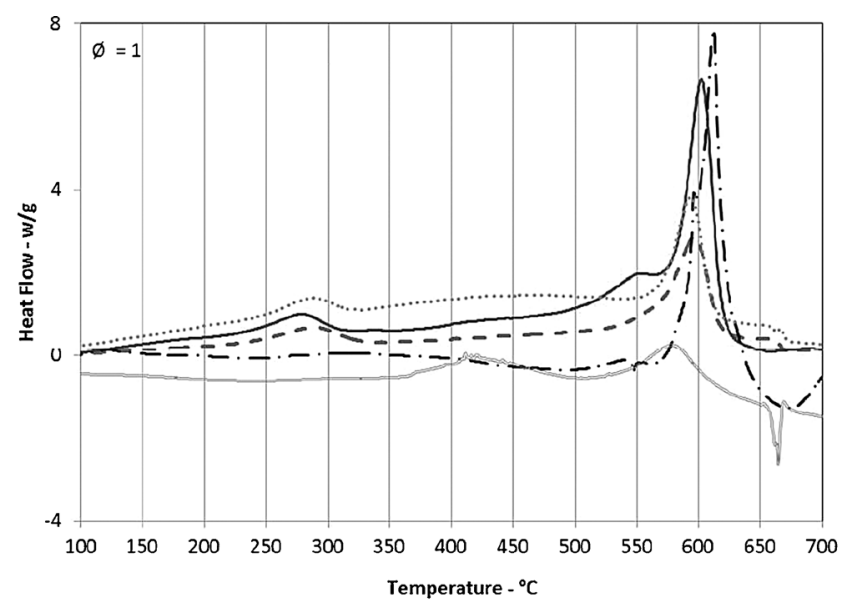

- - $200 \mathrm{~nm}-\mathrm{Al} / 400 \mathrm{~nm}-\mathrm{CuO} \longrightarrow 100 \mathrm{~nm}-\mathrm{Al} / 200 \mathrm{~nm}-\mathrm{CuO}-.-50 \mathrm{~nm}-\mathrm{Al} / 100 \mathrm{~nm}-\mathrm{CuO}$ ...... $300 \mathrm{~nm}-\mathrm{Al} / 600 \mathrm{~nm}-\mathrm{CuO} \longrightarrow 500 \mathrm{~nm}-\mathrm{Al} / 1000 \mathrm{~nm}-\mathrm{CuO}$

Figure 10. DSC curves of $\mathrm{Al} / \mathrm{CuO}$ nanolaminates heated at $10^{\circ} \mathrm{C} \mathrm{min}^{-1}$ and for different are detected.

spond to the tetragonal khatyrkite $\mathrm{CuAl}_{2}$ phase $(14 / \mathrm{mcm}$ space group, $a=0.607 \mathrm{~nm}$ and $c=0.487 \mathrm{~nm}$ ). For stoichiometric ratio $\varnothing=1, \mathrm{CuAl}_{2}$ and also $\mathrm{Cu}_{2} \mathrm{O}$ and $\mathrm{Cu}_{9} \mathrm{Al}_{4}$ are detected. $\mathrm{Al}_{2} \mathrm{O}_{3}$ cannot be detected since it is amorphous. In XRD pattern, Al peaks seen in the as-deposited foil [18] remain only in fuel rich samples. They are no longer present for $\varnothing=1$ and $2 / 3$. To complement XRD studies, Raman spectra (see Figure 9) were recorded on reacted foils $(\varnothing=1)$ to confirm XRD analysis and detect amorphous alumina. The characteristic phonon frequencies of $\mathrm{CuAl}_{2}$ (at 103 and $260 \mathrm{~cm}^{-1}$ ) and $\mathrm{Cu}_{2} \mathrm{O}\left(\right.$ at $226 \mathrm{~cm}^{-1}$ ) and those of amorphous $\mathrm{Al}_{2} \mathrm{O}_{3}$ at 416,625 and $765 \mathrm{~cm}^{-1}$ are observed.

To assess quantitatively the effect of bilayer thickness on the thermal decomposition, DSC analyses on stoichiometric $\mathrm{Al} / \mathrm{CuO}$ samples with different individual Al film thicknesses, or bilayer thicknesses were performed. For each experiment, three samples were tested and the average value is given in the graph of Figure 11.

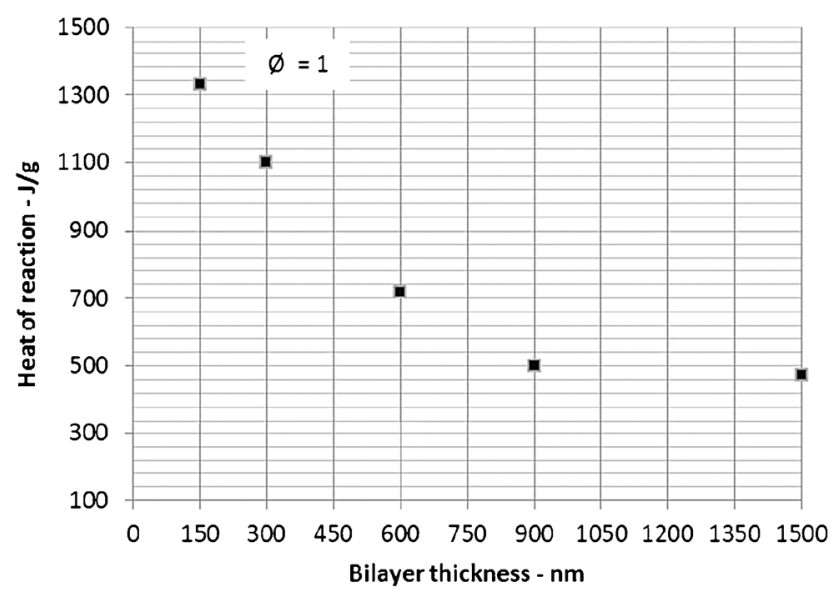

Figure 11. Heat of reaction as a function of bilayer thickness.

The DSC curves of Figure 10 clearly show that the heat of reaction is affected by the thickness of Al. At constant heating rate, the heat of reaction generated by $\mathrm{Al} / \mathrm{CuO}$ reaction decreases when thickening the Al layer above $100 \mathrm{~nm}$. The highest reactivity is obtained for bilayer thickness of $150 \mathrm{~nm}$ (Al-50 nm/CuO-100 nm). For the thickest bilayers (Al-500 nm/CuO-1 $\mu \mathrm{m}$ ), only $10 \%$ of the theoretical heat of reaction is released and the endothermic aluminum fusion peak seen after $600^{\circ} \mathrm{C}$ proves that all the bulk aluminum did not react at low temperature. It seems that only the region near the interface reacts below $600^{\circ} \mathrm{C}$. The best configuration is obtained for bilayer thickness of $150 \mathrm{~nm}$. In that case, the experimental heat of reaction reaches $40 \%$ of the theoretical value, which is $3.1 \mathrm{~kJ} \mathrm{~g}^{-1}$.

In Figure 11, the heat of reaction calculated by integrating the DSC curves in the range of $400-600^{\circ} \mathrm{C}$ over the time, divided by the sample mass are plotted. The maximum value is obtained for bilayer thickness of $150 \mathrm{~nm}$ $(50 \mathrm{~nm}-\mathrm{Al} / 100 \mathrm{~nm}-\mathrm{CuO})$. This enhanced reactivity for stoichiometric nanolaminates being composed of ultra-thin Al and $\mathrm{CuO}$ layers could be attributed to the very short time needed for $\mathrm{Al}$ and $\mathrm{O}$ to travel through their respective layers and through the diffusion barrier layers before reacting together.

\subsection{Effect of Stoichiometry and Bilayer Thickness on Burning Rate}

The graph of Figure 12 giving the burning rate as a function of bilayer thickness shows that the burning rate decreases from $80 \mathrm{~m} \mathrm{~s}^{-1}$ (obtained for $150 \mathrm{~nm}$ thick bilayer) to $1.5 \mathrm{~m} \mathrm{~s}^{-1}$ for the thickest bilayer. These burning rates are well below those reported for nanopowder mixing. For example Weismiller et al. [38] have measured burning rates of several hundreds of $\mathrm{ms}^{-1}$ in an open burning tray for $\mathrm{Al} / \mathrm{MoO}_{3}$ mixture. Dikici et al. [39] have measured flame speed of $285 \mathrm{~m} \mathrm{~s}^{-1}$ for $\mathrm{Al}-80 \mathrm{~nm} / \mathrm{MoO}_{3}-44 \mathrm{~nm}$ mixture. Ap- 


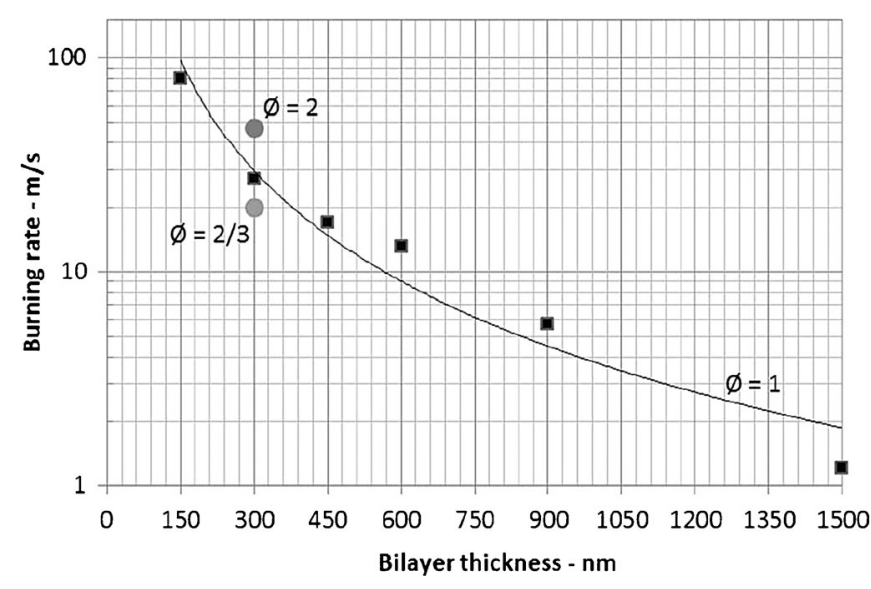

Figure 12. Burning rate as a function of $\mathrm{Al} / \mathrm{CuO}$ bilayer thickness for stoichiometric ratio. Two additional characterization points are added for $\varnothing=2$ and $\varnothing=2 / 3$.

person et al. [40] have reported combustion rates of 1500$2300 \mathrm{~m} \mathrm{~s}^{-1}$ for $\mathrm{CuO}$ nanorod mixed with Al nanoparticles. However, Weihs et al. [17] have measured, for sputtered $\mathrm{Al} / \mathrm{CuO}_{x^{\prime}}$ a combustion rate of $1 \mathrm{~m} \mathrm{~s}^{-1}$ for a foil thickness of $1 \mu \mathrm{m}$, which is in good agreement with our results.

\section{Conclusion}

$\mathrm{Al} / \mathrm{CuO}$ nanolaminates were sputter deposited and their structural, morphological, and chemical properties were characterized by high resolution transmission electron microscopy, X-ray diffraction, X-ray photoelectron spectroscopy, and STEM-EDX. The interface formed upon Al deposition on $\mathrm{CuO}$ layer induces a penetration of $\mathrm{Al}$ atoms into the $\mathrm{CuO}$ layer, leading to $\mathrm{Cu}^{2+}$ reduction and formation of a Cu-Al-O mixture with an irregular thickness not exceeding $5 \mathrm{~nm}$. XPS showed that the interface is a mix between $\mathrm{Al}_{2} \mathrm{O}_{3} \cdot \mathrm{AlO}_{x}$ and $\mathrm{Cu}$ mainly unoxidized. The interface formed upon $\mathrm{CuO}$ deposition on $\mathrm{Al}$ layer is regular in thickness (about $4 \mathrm{~nm}$ ). A very thin $\mathrm{Al}_{2} \mathrm{O}_{3}$ layer is probably formed when $\mathrm{O}_{2}$ plasma is generated inside the chamber just before starting the $\mathrm{Cu}$ sputtering. This interface grows with the $\mathrm{CuO}$ deposition. This interface is mainly composed of $\mathrm{Al}_{2} \mathrm{O}_{3}$, copper oxide, and $\mathrm{Al}$ metal. It is also noted that this interface, formed when $\mathrm{CuO}$ is sputtered on $\mathrm{Al}$, is thicker than the native $\mathrm{Al}$ oxide. Besides, $\mathrm{CuO}$ is easily reduced close to the interface to form alumina or Al-O-Cu mixture. It was also observed that copper atoms (from copper oxide layer) migrate easily, through the intermixed interface layer, into the $\mathrm{Al}$ layer and remains into the $\mathrm{Al}$ film bonded to $\mathrm{Al}$ atoms.

It could be experimentally observed that the optimum equivalence ratio for sputtered deposited $\mathrm{Al} / \mathrm{CuO}$ nanolaminates is 2 . It is possible to tailor the burning rate as desired just by adjusting the $\mathrm{Al} / \mathrm{CuO}$ bilayer thickness. For the stoichiometric nanolaminates $(\varnothing=1)$ the reactivity quickly in- creases with the decrease of bilayer thickness. The burning rate was of $2 \mathrm{~m} \mathrm{~s}^{-1}$ for $1500 \mathrm{~nm}$ thick bilayer and reached $80 \mathrm{~m} \mathrm{~s}^{-1}$ for the $150 \mathrm{~nm}$ thick bilayer. The maximum heat of reaction is obtained for $\varnothing=2$ and not 1 , as expected. This is probably due to oxygen diffusion from $\mathrm{CuO}$ to the interface where the density of oxygen atoms is important. Finally, this paper demonstrates the possibility to easily adapt the $\mathrm{Al} / \mathrm{CuO}$ nanolaminates reactivity by changing the layer thickness. These $\mathrm{Al} / \mathrm{CuO}$ nanolaminates can also be directly integrated onto MEMS devices so that they can be used in a broad spectrum of pyrotechnic applications. The fabrication process and the tunable performance could therefore find many useful applications in future energetic micro-actuation systems.

\section{Acknowledgments}

This work was supported by French National Space Agency (CNES) and the authors would like to thank the French Technological Network namely RENATECH that has partially funded the sputter deposition equipment. The authors also thank J. Esvan from CIRIMAT who performed the X-ray photoelectron spectroscopy.

\section{References}

[1] M. Jitaru, F. Kormos, C. Roman, M. Pavai, G. Tolnai, E. Kalman, Investigation on Nanostructured Metal Oxide Composite Material with Electrocatalytical Properties, Cas 2005, Int. Semicond. Conference, Vol 1 and 2, 69-72, 2005.

[2] M. R. Zachariah, NanoEnergetics: Hype, Reality, and Future, Propellants Explos. Pyrotech. 2013, 38, 7.

[3] C. Rossi, A. Esteve, P. Vashishta, Nanoscale Energetic Materials, J. Phys. Chem. Solids 2010, 71, 57-58.

[4] M. L. Pantoya, E. M. Hunt, Nanochargers: Energetic Materials for Energy Storage, Appl. Phys. Lett. 2009, 95.

[5] C. C. Trapalis, M. Kokkoris, G. Perdikakis, G. Kordas, Study of Antibacterial Composite $\mathrm{Cu} / \mathrm{SiO}_{2}$ Thin Coatings, J. Sol-Gel Sci. Technol. 2003, 26, 1213-1218.

[6] K. Vasilev, J. Cook, H. J. Griesser, Antibacterial Surfaces for Biomedical Devices, Expert Rev. Med. Devices 2009, 6, 553-567.

[7] M. H. Cho, Y. S. Roh, C. N. Whang, K. Jeong, H. J. Choi, S. W. Nam, D.-H. Ko, J. H. Lee, N. I. Lee, K. Fujihara, Dielectric Characteristics of $\mathrm{Al}_{2} \mathrm{O}_{3}-\mathrm{HfO}_{2}$ Nanolaminates on $\mathrm{Si}(100)$, Appl. Phys. Lett. 2002, 81, 1071-1073.

[8] M. Leskela, M. Kemell, K. Kukli, V. Pore, E. Santala, M. Ritala, J. Lu, Exploitation of Atomic Layer Deposition for Nanostructured Materials, Mater. Sci. Eng. C, 2007, 27, 1504-1508.

[9] Z. A. Sechrist, F. H. Fabreguette, O. Heintz, T. M. Phung, D. C. Johnson, S. M. George, Optimization and Structural Characterization of $\mathrm{W} / \mathrm{Al}_{2} \mathrm{O}_{3}$ Nanolaminates Grown using Atomic Layer Deposition Techniques, Chem. Mater. 2005, 17, 3475-3485.

[10] R. K. Grubbs, C. E. Nelson, N. J. Steinmetz, S. M. George, Nucleation and Growth during the Atomic Layer Deposition of W on $\mathrm{Al}_{2} \mathrm{O}_{3}$ and $\mathrm{Al}_{2} \mathrm{O}_{3}$ on W, Thin Solid Films 2004, 467, 16-27.

[11] J. T. Anderson, C. L. Munsee, C. M. Hung, T. M. Phung, G. S. Herman, D. C. Johnson, J.F. Wager, D. A. Keszler, Solution-Processed $\mathrm{HafSO}_{\mathrm{x}}$ and $\mathrm{ZirCSO}_{\mathrm{x}}$ Inorganic Thin-film Dielectrics and Nanolaminates, Adv. Funct. Mater. 2007, 17, 2117-2124.

[12] K. Karakaya, B. Barcones, Z. M. Rittersma, J. G. M. van Berkum, M. A. Verheijen, G. Rijnders, D. H. A. Blank, Electrical and Struc- 
tural Characterization of PLD Grown $\mathrm{CeO}_{2}-\mathrm{HfO}_{2}$ Laminated High-k Gate Dielectrics, Mater. Sci. Semicond. Process. 2006, 9, 1061-1064.

[13] T. P. Weihs, T. W. Barbee, M. A. Wall, Hardness, Ductility, and Thermal Processing of $\mathrm{Cu} / \mathrm{Zr}$ and $\mathrm{Cu} / \mathrm{Cu}-\mathrm{Zr}$ Nanoscale Multilayer Foils, Acta Mater. 1997, 45, 2307-2315.

[14] P. Sharma, W. Zhang, K. Amiya, H. Kimura, A. Inoue, Nanoscale Patterning of Zr-Al-Cu-Ni Metallic Glass Thin Flms Deposited by Magnetron Sputtering, J. Nanosci. Nanotechnol. 2005, 5, $416-420$.

[15] K. J. Blobaum, D. Van Heerden, A. J. Gavens, T. P. Weihs, Al/Ni Formation Reactions: Characterization of the Metastable $\mathrm{Al}_{9} \mathrm{Ni}_{2}$ Phase and Snalysis of its Gormation, Acta Mater. 2003, 51, 3871-3884.

[16] K. J. Blobaum, A. J. Wagner, J. M. Plitzko, D. Van Heerden, D. H. Fairbrother, T. P. Weihs, Investigating the Reaction Path and Growth Kinetics in $\mathrm{CuO}_{x} / \mathrm{Al}$ Multilayer Foils, J. Appl. Phys. 2003, 94, 2923-2929.

[17] K. J. Blobaum, M. E. Reiss, J. M. P. Lawrence, T. P. Weihs, Deposition and Characterization of a Self-Propagating $\mathrm{CuO}_{x} / \mathrm{Al}$ Thermite Reaction in a Multilayer Foil Geometry, J. Appl. Phys. 2003, 94, 2915-2922.

[18] M. Petrantoni, C. Rossi, L. Salvagnac, V. Conedera, A. Esteve, C. Tenailleau, P. Alphonse, Y. J. Chabal, Multilayered Al/CuO Thermite Formation by Reactive Magnetron Sputtering: Nano vs. Micro, J. Appl. Phys. 2010, 108, 084323.

[19] N. A. Manesh, S. Basu, R. Kumar, Experimental Fame Speed in Multi-Layered Nano-Energetic Materials, Combust. Flame 2010, 157, 476-480.

[20] S. T. Meyers, J. T. Anderson, D. Hong, C. M. Hung, J. F. Wager, D. A. Keszler, Solution-Processed Aluminum Oxide Phosphate Thin-film Dielectrics, Chem. Mater. 2007, 19, 4023-4029.

[21] C. D. Yarrington, S. F. Son, T. J. Foley, S. J. Obrey, A. N. Pacheco, Nano Aluminum Energetics: The Effect of Synthesis Method on Morphology and Combustion Performance, Propellants Explos. Pyrotech. 2011, 36, 551-557.

[22] B. W. Asay, S. E. Son, J. R. Busse, D. M. Oschwald, Ignition Characteristics of Metastable Intermolecular Composites, Propellants Explos. Pyrotech. 2004, 29, 216-219.

[23] T. Foley, A. Pacheco, J. Malchi, R. Yetter, K. Higa, Development of Nanothermite Composites with Variable Electrostatic Discharge Ignition Thresholds, Propellants Explos. Pyrotech. 2007, $32,431-434$.

[24] T. R. Sippel, T. L. Pourpoint, S. F. Son, Combustion of Nanoaluminum and Water Propellants: Effect of Equivalence Ratio and Safety/Aging Characterization, Propellants Explos. Pyrotech. 2013, 38, 56-66.

[25] A. E. Stiegman, C. D. Park, M. Mileham, L. J. van de Burgt, M. P. Kramer, Dynamics of $\mathrm{Al} / \mathrm{Fe}_{2} \mathrm{O}_{3}$ MIC Combustion from Short Single-Pulse Photothermal Initiation and Time-Resolved Spectroscopy, Propellants Explos. Pyrotech. 2009, 34, 293-296.

[26] S. M. Umbrajkar, M. Schoenitz, E. L. Dreizin, Control of Structural Refinement and Composition in $\mathrm{Al}-\mathrm{MoO}_{3}$ Nanocomposites Prepared by Arrested Reactive Milling, Propellants Explos. Pyrotech. 2006, 31, 382-389.
[27] C. Rossi, K. Zhang, D. Esteve, P. Alphonse, P. Tailhades, C. Vahlas, Nanoenergetic Materials for MEMS: A Review, J. Microelectromech. Syst. 2007, 16, 919-931.

[28] K. Zhang, C. Rossi, G. A. A. Rodriguez, C. Tenailleau, P. Alphonse, Development of a Nano-Al/CuO Based Energetic Material on Silicon Substrate, Appl. Phys. Lett, 2007, 91.

[29] T. B. Brill, K. J. James, Kinetics and Mechanisms of Thermal-Decomposition of Nitroaromatic Explosives, Chem. Rev. 1993, 93, $2667-2692$.

[30] N. Amini-Manesh, S. Basu, R. Kumar, Modeling of a Reacting Nanofilm on a Composite Substrate, Energy 2011, 36, 16881697.

[31] J. A. Thornton, The Microstructure of Sputter-Deposited Coatings, J. Vac. Sci. Technol. A 1986, 4, 3059-3065.

[32] J. Kwon, J. M. Ducere, P. Alphonse, M. Bahrami, M. Petrantoni, J.-F. Veyan, C. Tenailleau, A. Estève, C. Rossi, Y. J. Chabal, Interfacial Chemistry in $\mathrm{Al} / \mathrm{CuO}$ Reactive Nanomaterial and its Role in Exothermic Reactions, ACS Appl. Mater. Interfaces 2013, 5, $605-613$.

[33] P. S. Wang, L. D. Haws, W. E. Moddeman, A. Rengan, Al/Cu20 Thermite Compatibility Studies by X-ray Photo-Electron and Xray-Induced Auger-Spectroscopy, J. Hazard. Mater. 1982, 8, 297-308.

[34] S. Y. Lee, N. Mettlach, N. Nguyen, Y. M. Sun, J. M. White, Copper Oxide Reduction Through Vacuum Annealing, Appl. Surf. Sci. 2003, 206, 102-109.

[35] S. M. Umbrajkar, M. Schoenitz, E. L. Dreizin, Exothermic Reactions in Al-CuO Nanocomposites, Thermochim. Acta 2006, 451, $34-43$.

[36] A. Ermoline, D. Stamatis, E. L. Dreizin, Low-Remperature Exothermic Reactions in Fully Dense Al-CuO Nanocomposite Powders, Thermochim. Acta 2012, 527, 52-58.

[37] D. Stamatis, Z. Jiang, V. Hoffmann, M. Schoenitz, E. Dreizin, Fully Dense, Aluminum-Rich Al-CuO Nanocomposite Powders for Energetic Formulations, Combust. Sci. Technol. 2009, 181, 97-116.

[38] M. R. Weismiller, J. Y. Malchi, R. A. Yetter, T. J. Foley, Dependence of Flame Propagation on Pressure and Pressurizing Gas for an Al/CuO Nanoscale Thermite, Proc. Combust. Inst. 2009, $32,1895-1903$.

[39] B. Dikici, S. W. Dean, M. L. Pantoya, V. I. Levitas, R. J. Jouet, Influence of Aluminum Passivation on the Reaction Mechanism: Flame Propagation Studies, Energy Fuels 2009, 23, 4231-4235.

[40] S. Apperson, R. V. Shende, S. Subramanian, D. Tappmeyer, S. Gangopadhyay, Z. Chen, K. Gangopadhyay, P. Redner, S. Nicholich, D. Kapoor, Generation of Fast Propagating Combustion and Shock Waves with Copper Oxide/Aluminum Nanothermite Composites, Appl. Phys. Lett. 2007, 91, 243109. 